\title{
Tumebacillus ginsengisoli sp. nov., isolated from soil of a ginseng field
}

\author{
Sang-Hoon Baek, ${ }^{1}$ Yingshun Cui, ${ }^{1}$ Sun-Chang Kim, ${ }^{1,2}$ Chang-Hao Cui, ${ }^{1}$ \\ Chengri Yin, ${ }^{3}$ Sung-Taik Lee ${ }^{1}$ and Wan-Taek $\operatorname{Im}^{1,2}$
}

Correspondence
Wan-Taek Im
wandra@kaist.ac.kr
Sung-Taik Lee
e_stlee@kaist.ac.kr

\author{
${ }^{1}$ Department of Biological Sciences, Korea Advanced Institute of Science and Technology, 373-1, \\ Guseong-dong, Yuseong-gu, Daejeon 305-701, Republic of Korea \\ ${ }^{2}$ KAIST Institute for Biocentry, Korea Advanced Institute of Science and Technology, 373-1, \\ Guseong-dong, Yuseong-gu, Daejeon 305-701, Republic of Korea \\ ${ }^{3}$ Key Laboratory for Natural Resources of Changbai Mountain and Functional Molecules (Yanbian \\ University), Ministry of Education, Yanji 133002, PR China
}

The genus Tumebacillus was proposed by Steven et al. (2008) to accommodate a Gram-positive, aerobic, sporeforming, rod-shaped, non-motile bacterium. Only one species of the genus, Tumebacillus permanentifrigoris, is currently recognized. The genus Tumebacillus forms a phylogenetically distinct line of descent that is close to, but separate from, members of the genus Alicyclobacillus. During the course of a study on the culturable aerobic and facultatively anaerobic bacterial community present in a soil sample from a ginseng field in Pocheon Province, South Korea, a large number of novel bacterial strains were isolated (Im et al., 2005). In this study, we have characterized one of these isolates, strain Gsoil $1105^{\mathrm{T}}$. Phenotypic, chemotaxonomic and phylogenetic analyses establish the affiliation of the isolate to the genus Tumebacillus. The data obtained also suggest that this isolate represents a novel species of the genus Tumebacillus.

The ginseng field soil sample was thoroughly suspended in $50 \mathrm{mM}$ phosphate buffer $(\mathrm{pH} 7.0)$ and the suspension was spread on one-fifth-strength modified R2A agar plates

The GenBank/EMBL/DDBJ accession number for the 16S rRNA gene sequence of strain Gsoil $1105^{\top}$ is AB245375.

Two supplementary figures are available with the online version of this paper. [containing $\left(\mathrm{l}^{-1}\right)$ : $0.25 \mathrm{~g}$ tryptone, $0.25 \mathrm{~g}$ peptone, $0.25 \mathrm{~g}$ yeast extract, $0.125 \mathrm{~g}$ malt extract, $0.125 \mathrm{~g}$ beef extract, 0.25 g Casamino acids, 0.25 g soytone, 0.5 g glucose, $0.3 \mathrm{~g}$ soluble starch, $0.2 \mathrm{~g}$ xylan, $0.3 \mathrm{~g}$ sodium pyruvate, $0.3 \mathrm{~g}$ $\mathrm{K}_{2} \mathrm{HPO}_{4}, 0.05 \mathrm{~g} \mathrm{MgSO}_{4}, 0.05 \mathrm{~g} \mathrm{CaCl}_{2}, 15 \mathrm{~g}$ agar] after being serially diluted with $50 \mathrm{mM}$ phosphate buffer ( $\mathrm{pH}$ 7.0). The plates were incubated for a month at room temperature. Single colonies on the plates were incubated once again under aerobic conditions using modified R2A agar or half-strength modified R2A agar. Purified colonies were tentatively identified from partial sequences of the $16 \mathrm{~S}$ rRNA gene (Im et al., 2005). Strain Gsoil $1105^{\mathrm{T}}$ was one of the isolates that appeared on modified R2A agar plates grown under aerobic conditions; this strain was routinely cultured on R2A agar (BD) at $30{ }^{\circ} \mathrm{C}$ and maintained as a glycerol suspension $(20 \%, \mathrm{w} / \mathrm{v})$ at $-70{ }^{\circ} \mathrm{C}$.

The Gram reaction was assessed by the non-staining method as described by Buck (1982). Cell morphology and motility were examined by phase-contrast microscopy, using cells grown for 2 days at $30{ }^{\circ} \mathrm{C}$ on R2A agar. Catalase activity was determined from bubble production in $3 \%(\mathrm{v} / \mathrm{v})$ $\mathrm{H}_{2} \mathrm{O}_{2}$. Oxidase activity was determined using $1 \%(\mathrm{w} / \mathrm{v})$ tetramethyl $p$-phenylenediamine. Anaerobic growth was tested in serum bottles containing R2A broth supplemented with thioglycolate $\left(\mathrm{g} \mathrm{l}^{-1}\right)$ and in which the headspace 
was replaced with nitrogen gas. Tests for the degradation of DNA [DNase agar (Scharlau), tested by flooding plates with 1.0 M HCl], casein, chitin, starch (Atlas, 1993), lipid (Kouker \& Jaeger, 1987), xylan and cellulose (Ten et al., 2004) were evaluated after 5 days. Nitrate reduction was determined aerobically in a serum bottle supplemented with $10 \mathrm{mM} \mathrm{KNO}_{3}$ as an electron donor and was monitored by using an ion chromatograph (Metrohm) equipped with a conductivity detector and anion exchange column. Growth on R2A medium at 4, 10, 15, $20,30,37,42$ and $50{ }^{\circ} \mathrm{C}$ and at $\mathrm{pH} 4.0-10.0$ (in increments of $0.5 \mathrm{pH}$ units) was assessed after 5 days of incubation. Salt tolerance was tested on R2A medium supplemented with $1-10 \%(\mathrm{w} / \mathrm{v}) \mathrm{NaCl}$ after 5 days of incubation. Growth on nutrient agar, trypticase soy agar and MacConkey agar was also evaluated at $30{ }^{\circ} \mathrm{C}$.

For studies on the assimilation of single carbon sources, a defined agar medium was used that contained a basal salt mixture $\left(\mathrm{l}^{-1}: 1.8 \mathrm{~g} \mathrm{~K}_{2} \mathrm{HPO}_{4}, 1.08 \mathrm{~g} \mathrm{KH}_{2} \mathrm{PO}_{4}, 0.5 \mathrm{~g} \mathrm{NaNO}_{3}\right.$, $0.5 \mathrm{~g} \mathrm{NH}_{4} \mathrm{Cl}, 0.1 \mathrm{~g} \mathrm{KCl}, 0.1 \mathrm{~g} \mathrm{MgSO}_{4}, 0.05 \mathrm{~g} \mathrm{CaCl}_{2}, 15.0 \mathrm{~g}$ agar). A vitamin solution (Widdel \& Bak, 1992), a trace element solution (SL-10; Widdel et al., 1983) and selenite/ tungstate solution (Tschech \& Pfennig, 1984) were added to this medium and the medium was adjusted to $\mathrm{pH} 6.8$ by the addition of $1.0 \mathrm{M} \mathrm{HCl}$. Filter-sterilized carbon sources were added individually to the agar medium [at $0.1 \%(\mathrm{w} /$ v)] and the plates were incubated at $30{ }^{\circ} \mathrm{C}$ for up to 5 days. The negative control agar plate did not contain any carbon source and a positive control culture was grown on R2A agar. Acid production from glucose was examined in BBL phenol red broth base (Difco) prepared with $1 \%$ $(\mathrm{w} / \mathrm{v})$ glucose added. Duplicate antibiotic sensitivity tests were performed using filter-paper discs containing the following: ampicillin, chloramphenicol, erythromycin, gentamicin, lincomycin, penicillin and streptomycin, each at $5,10,30,50$ and $100 \mu \mathrm{g} \mathrm{ml}^{-1}$. Discs were placed on R2A agar plates spread with strain Gsoil $1105^{\mathrm{T}}$ and
T. permanentifrigoris DSM $18773^{\mathrm{T}}$ (reference strain) and the plates were then incubated at $30{ }^{\circ} \mathrm{C}$ for 5 days.

Extraction of genomic DNA was performed with a commercial genomic DNA-extraction kit (Core Biosystem) and PCR-mediated amplification of the $16 \mathrm{~S}$ rRNA gene and sequencing of the purified PCR product were carried out according to Ten et al. (2008). The $16 \mathrm{~S}$ rRNA sequence of strain Gsoil $1105^{\mathrm{T}}$ was assembled with Seqman II 5.0 (DNASTAR) (Swindell \& Plasterer, 1997) and compared with all bacterial 16S rRNA gene sequences available in the GenBank database. Alignment of 23 related sequences was carried out with CLUSTAL_X (Thompson et al., 1997). Gaps at the $5^{\prime}$ and $3^{\prime}$ ends and ambiguous bases were removed from the alignment using BioEdit (Hall, 1999). Phylogenetic trees based on comparison of 1405 bases were reconstructed by the neighbour-joining (Saitou \& Nei, 1987) and maximum-parsimony (Fitch, 1971) algorithms using MEGA version 3.1 (Kumar et al., 2004). The maximum-likelihood method was also used for phylogenetic analysis, using the program DNAML in the PHYLIP software package (Felsenstein, 1989). Evolutionary distances were calculated using Kimura's two-parameter model (Kimura, 1983) and bootstrap values were based on 1000 replications (Felsenstein, 1985).

To determine the $\mathrm{G}+\mathrm{C}$ content of the chromosomal DNA, genomic DNA of the novel strain was extracted and purified as described by Moore \& Dowhan (1995) and enzymically degraded into nucleosides. The DNA G $+\mathrm{C}$ content was determined as described by Mesbah et al. (1989) using a reversed-phase HPLC. Isoprenoid quinones were extracted with chloroform/methanol $(2: 1, \mathrm{v} / \mathrm{v})$, evaporated under a vacuum and re-extracted in $n$-hexane/water $(1: 1, \mathrm{v} / \mathrm{v})$. The crude quinone in the $\mathrm{n}$-hexane solution was purified using Sep-Pak (Waters) and subsequently analysed by HPLC as described previously (Hiraishi et al., 1996). Cellular fatty acids of strain Gsoil $1105^{\mathrm{T}}$ and T. permanentifrigoris DSM $18773^{\mathrm{T}}$ were determined after growth on R2A agar (Difco)

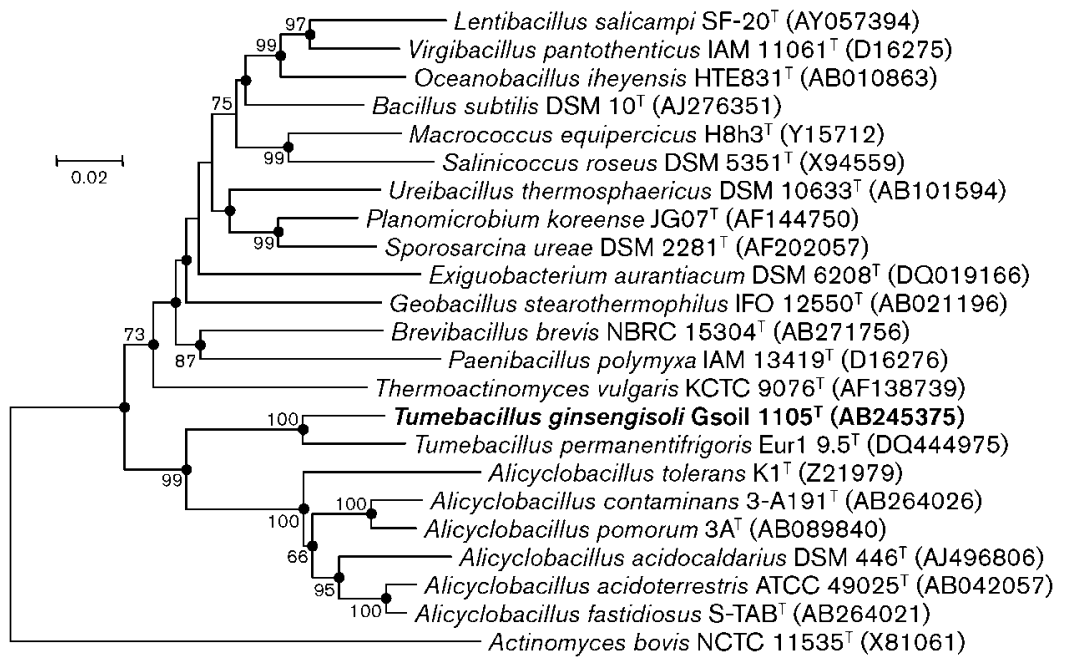

Fig. 1. Neighbour-joining phylogenetic tree, reconstructed from a comparative analysis of 16S rRNA gene sequences, showing the relationships between strain Gsoil $1105^{\top}$ and related species. Filled circles indicate generic branches that were also recovered by using the maximum-parsimony algorithm. Bootstrap values (expressed as percentages of 1000 replications) greater than $65 \%$ are shown at branch points. Bar, 0.02 substitutions per nucleotide position. 
for 2 days. Cellular fatty acids methyl esters were prepared and identified following the protocol of the Sherlock Microbial Identification System (MIDI). Determination of peptidoglycan structure were carried out by the methods described by Schleifer \& Kandler (1972).

Cells of strain Gsoil $1105^{\mathrm{T}}$ were found to be Gramreaction-positive, aerobic, non-motile rods, $0.5-0.8 \mu \mathrm{m}$ wide and 3.0-6.0 $\mu \mathrm{m}$ long. Phase-contrast microscopy revealed that cells of strain Gsoil $1105^{\mathrm{T}}$ formed ellipsoidal spores in large terminal sporangia (Supplementary Fig. S1, available in IJSEM Online). The novel strain was able to grow aerobically using nitrate as a terminal electron acceptor. Colonies grown on R2A agar plates (Difco) for 2 days were circular, concentric, serrate, white, raised and 1-2 $\mathrm{mm}$ in diameter. Growth was not observed on nutrient

Table 1. Phenotypic and physiological characteristics of strain Gsoil $1105^{\top}$ and T. permanentifrigoris DSM $18773^{\top}$

Strains: 1 , Gsoil $1105^{\mathrm{T}} ; 2$, T. permanentifrigoris DSM $18773^{\mathrm{T}}$. Data for both strains were from this study. Both strains tested positive for hydrolysis of casein and starch, sensitivity to ampicillin, chloramphenicol, penicillin and streptomycin and assimilation of cellobiose, D-galactose, D-glucose, lactose, D-mannitol, trehalose and lactate. Both strains were negative for catalase activity, hydrolysis of xylan, chitin, aesculin, cellulose and DNA, acid production from Dglucose and assimilation of D-arabinose, L-sorbose and L-xylose. +, Positive; $\mathrm{W}$, weakly positive; -, negative; $\mathrm{R}$, resistant; $\mathrm{s}$, sensitive.

\begin{tabular}{|c|c|c|}
\hline Characteristic & 1 & 2 \\
\hline Colony colour & White & Yellow \\
\hline Cell size $(\mu \mathrm{m})$ & $3-6 \times 0.5-0.8$ & $3-3.5 \times 0.5$ \\
\hline \multicolumn{3}{|l|}{ Ranges for growth } \\
\hline Temperature $\left({ }^{\circ} \mathrm{C}\right)$ & $20-42$ & $10-37$ \\
\hline $\mathrm{pH}$ & $5.0-8.5$ & $5.5-9.0$ \\
\hline Oxidase & + & - \\
\hline \multicolumn{3}{|c|}{ Response to antibiotics (per disc) } \\
\hline Erythromycin $(10 \mu \mathrm{g})$ & $\mathrm{R}$ & s \\
\hline Gentamicin $(10 \mu \mathrm{g})$ & $\mathrm{R}$ & s \\
\hline Lincomycin $(30 \mu \mathrm{g})$ & $\mathrm{R}$ & s \\
\hline Penicillin $(5 \mu \mathrm{g})$ & s & $\mathrm{R}$ \\
\hline \multicolumn{3}{|l|}{ Assimilation of: } \\
\hline Sucrose & + & $\mathrm{w}$ \\
\hline L-Arabinose & + & W \\
\hline Melibiose & + & $\mathrm{W}$ \\
\hline Alanine & + & $\mathrm{W}$ \\
\hline D-Mannose & + & $\mathrm{W}$ \\
\hline Salicin & + & $\mathrm{w}$ \\
\hline Pyruvic acid & + & - \\
\hline D-Xylose & + & - \\
\hline D-Sorbitol & $\mathrm{W}$ & - \\
\hline D-Fructose & - & + \\
\hline Maltose & - & + \\
\hline Fumaric acid & - & w \\
\hline Citrate & - & $\mathrm{w}$ \\
\hline$N$-Acetylglucosamine & - & $\mathrm{w}$ \\
\hline Gluconate & - & $\mathrm{W}$ \\
\hline
\end{tabular}

agar, MacConkey agar or trypticase soy agar. Strain Gsoil $1105^{\mathrm{T}}$ was able to grow on R2A agar at $20-42{ }^{\circ} \mathrm{C}$; no growth was observed at 15 or $50{ }^{\circ} \mathrm{C}$.

The 16S rRNA gene sequence of strain Gsoil $1105^{\mathrm{T}}$ determined in this study was 1498 bp long. Sequence similarity calculations after a simple alignment analysis indicated that the closest relative of strain Gsoil $1105^{\mathrm{T}}$ was T. permanentifrigoris Eur1 9.5 ${ }^{\mathrm{T}}$ (94.6\%). Lower levels of sequence similarity $(<91.0 \%)$ were found to type strains of two other species in the order Bacillales, Alicyclobacillus pohliae $\mathrm{MP}^{\mathrm{T}}(91.0 \%)$ and $A$. contaminans $3-\mathrm{A} 191^{\mathrm{T}}$ $(89.4 \%)$. This relationship between strain Gsoil $1105^{\mathrm{T}}$ and other members of the order Bacillales was confirmed in the neighbour-joining phylogenetic tree (Fig. 1; using 1405 bases) and the maximum-likelihood phylogenetic tree (Supplementary Fig. S2; using 1405 bases). The phylogenetic trees indicate that strain Gsoil $1105^{\mathrm{T}}$ is closely related to the genus Tumebacillus. Gsoil $1105^{\mathrm{T}}$ formed a distinct cluster with $T$. permanentifrigoris Eur1 $9.5^{\mathrm{T}}$. The same results were obtained when the maximum-parsimony method was applied. Detailed characteristics that differentiate strain Gsoil $1105^{\mathrm{T}}$ from the type strain of $T$. permanentifrigoris are shown in Table 1.

The DNA G+C content of strain Gsoil $1105^{\mathrm{T}}$ was 55.6 mol\%. Strain Gsoil $1105^{\mathrm{T}}$ contained menaquinone 7 (MK-7) as the predominant isoprenoid quinone. The fatty

Table 2. Cellular fatty acid profiles of strain Gsoil $1105^{\top}$ and $T$. permanentifrigoris DSM $18773^{\top}$

Strains: 1 , Gsoil $1105^{\mathrm{T}} ; 2$, T. permanentifrigoris DSM $18773^{\mathrm{T}}$. Data for both strains are from this study using biomass grown under identical conditions and analysed with the Microbial Identification System. Values are percentages of total fatty acids; -, not detected. Major components $(>10 \%)$ are highlighted in bold.

\begin{tabular}{|c|c|c|}
\hline Fatty acid & 1 & 2 \\
\hline $\mathrm{C}_{14: 0}$ & 0.86 & 0.83 \\
\hline $\mathrm{C}_{16: 0}$ & 2.90 & 2.37 \\
\hline iso- $\mathrm{C}_{13: 0}$ & 0.49 & 1.15 \\
\hline iso- $\mathrm{C}_{14: 0}$ & 9.30 & 2.85 \\
\hline iso- $\mathrm{C}_{15: 0}$ & 43.03 & 56.21 \\
\hline iso- $\mathrm{C}_{16: 0}$ & 3.45 & 0.88 \\
\hline iso- $\mathrm{C}_{17: 0}$ & 0.94 & - \\
\hline iso- $\mathrm{C}_{16: 1} \mathrm{G}$ & 0.32 & - \\
\hline anteiso- $\mathrm{C}_{15: 0}$ & 35.59 & 13.66 \\
\hline anteiso- $\mathrm{C}_{17: 0}$ & 0.35 & - \\
\hline \multicolumn{3}{|c|}{ Summed features ${ }^{\star}$} \\
\hline 2 & 1.08 & 17.70 \\
\hline 4 & 0.27 & 1.00 \\
\hline 5 & 1.41 & 3.35 \\
\hline
\end{tabular}

${ }^{*}$ Summed feature 2 consists of one or more of iso- $\mathrm{C}_{15: 1} \mathrm{I}$, iso- $\mathrm{C}_{15: 1} \mathrm{H}$ and $\mathrm{C}_{13: 0} 3-\mathrm{OH}$. Summed feature 4 consists of $\mathrm{C}_{16: 1} \omega 7 c$ and/or iso$\mathrm{C}_{15: 0} 2-\mathrm{OH}$. Summed feature 5 consists of iso- $\mathrm{C}_{17: 1} \mathrm{I}$ and/or anteiso$\mathrm{C}_{17: 1} \mathrm{~B}$. 
acid profile of strain Gsoil $1105^{\mathrm{T}}$ (Table 2) was composed mainly of iso- $\mathrm{C}_{15: 0}(43.03 \%)$ and anteiso- $\mathrm{C}_{15: 0}(35.59 \%)$. The diagnostic diamino acid of the peptidoglycan was meso-diaminopimelic acid, suggesting the presence of peptidoglycan type Al $\gamma$. These chemotaxonomic data support the affiliation of strain Gsoil $1105^{\mathrm{T}}$ to the order Bacillales.

All characteristics determined for strain Gsoil $1105^{\mathrm{T}}$ were in accordance with those of the genus Tumebacillus. However, the phylogenetic distance from the sole recognized Tumebacillus species and the combination of unique phenotypic characteristics indicated that strain Gsoil $1105^{\mathrm{T}}$ is not affiliated to $T$. permanentifrigoris. Therefore, it is concluded that strain Gsoil $1105^{\mathrm{T}}$ represents a novel species of the genus Tumebacillus, for which the name Tumebacillus ginsengisoli sp. nov. is proposed.

\section{Description of Tumebacillus ginsengisoli sp. nov.}

Tumebacillus ginsengisoli (gin.sen.gi.so'li. N.L. n. ginsengum ginseng; L. n. solum soil; N.L. gen. n. ginsengisoli of the soil of a ginseng field, the source of the type strain).

Cells are Gram-reaction-positive, aerobic, non-motile rods, $0.5-0.8 \mu \mathrm{m}$ wide and $3.0-6.0 \mu \mathrm{m}$ long, after 2 days of culture on R2A agar. Forms white colonies on R2A plates, with no growth in liquid media. Colonies grown on R2A agar for 2 days are circular, concentric, serrate and raised. Terminal endospores are formed in swollen sporangia. Grows well at $20-42{ }^{\circ} \mathrm{C}$ and $\mathrm{pH} 5.0-8.5$, but not at 15 or $50{ }^{\circ} \mathrm{C}$. Growth occurs in the absence of $\mathrm{NaCl}$, but not in the presence of $1 \%(\mathrm{w} / \mathrm{v}) \mathrm{NaCl}$. It can reduce nitrate to nitrite. MK-7 is the predominant menaquinone. The major cellular fatty acids are iso- $C_{15: 0}$ and anteiso- $C_{15: 0}$. The peptidoglycan cell wall is of the $\mathrm{A} 1 \gamma$ type. In addition to the results given in Table 1, tests positive for utilization of the following substrates: D-fucose, L-rhamnose, acetate, phenylacetate, malate, glycerol, glycogen, dextran, glycine and serine. Utilization of D-ribose, D-raffinose, xylitol, cysteine and glutamic acid is weakly positive. Ethanol, formic acid, propionate, 3-hydroxybutyrate, valerate, caprate, maleic acid, benzoic acid, 3-hydroxybenzoic acid, 4-hydroxybenxoic acid, malonate, succinic acid, glutaric acid, tartaric acid, itaconate, adipate, suberate, oxalic acid, D-adonitol, dulcitol, inositol, amygdalin, inulin, asparagine, aspartic acid, histidine, isoleucine, leucine, phenylalanine, proline, threonine, tyrosine and valine do not serve as carbon sources for growth. The genomic DNA G $+\mathrm{C}$ content of the type strain is $55.6 \mathrm{~mol} \%$ (HPLC).

The type strain, Gsoil $1105^{\mathrm{T}}\left(=\mathrm{KCTC} 13942^{\mathrm{T}}=\mathrm{DSM}\right.$ $18389^{\mathrm{T}}$ ), was isolated from soil of a ginseng field in Pocheon Province, South Korea.

\section{Acknowledgements}

This work was supported by the 21C Frontier Microbial Genomics and Application Center Program, Ministry of Science and Technology, Republic of Korea (grant MG08-0101-2-0).

\section{References}

Atlas, R. M. (1993). Handbook of Microbiological Media. Edited by L. C. Parks. Boca Raton, FL: CRC Press.

Buck, J. D. (1982). Nonstaining $(\mathrm{KOH})$ method for determination of gram reactions of marine bacteria. Appl Environ Microbiol 44, 992993.

Felsenstein, J. (1985). Confidence limit on phylogenies: an approach using the bootstrap. Evolution 39, 783-791.

Felsenstein, J. (1989). PHYLIP - phylogeny inference package (version 3.2). Cladistics 5, 164-166.

Fitch, W. M. (1971). Toward defining the course of evolution: minimum change for a specific tree topology. Syst Zool 20, 406-416.

Hall, T. A. (1999). BioEdit: a user-friendly biological sequence alignment editor and analysis program for Windows 95/98/NT. Nucleic Acids Symp Ser 41, 95-98.

Hiraishi, A., Ueda, Y., Ishihara, J. \& Mori, T. (1996). Comparative lipoquinone analysis of influent sewage and activated sludge by highperformance liquid chromatography and photodiode array detection. J Gen Appl Microbiol 42, 457-469.

Im, W.-T., Jung, H.-M., Cui, Y.-S., Liu, Q.-M., Zhang, S.-L. \& Lee, S.-T. (2005). Cultivation of the three hundreds of bacterial species from soil of a ginseng field and mining the novel lineage bacteria. In Proceedings of the International Meeting of the Federation of Korean Microbiological Societies, abstract A035, p. 169. Seoul: Federation of Korean Microbiological Societies.

Kimura, M. (1983). The Neutral Theory of Molecular Evolution. Cambridge: Cambridge University Press.

Kouker, G. \& Jaeger, K.-E. (1987). Specific and sensitive plate assay for bacterial lipases. Appl Environ Microbiol 53, 211-213.

Kumar, S., Tamura, K. \& Nei, M. (2004). MEGA3: integrated software for molecular evolutionary genetics analysis and sequence alignment. Brief Bioinform 5, 150-163.

Mesbah, M., Premachandran, U. \& Whitman, W. B. (1989). Precise measurement of the $\mathrm{G}+\mathrm{C}$ content of deoxyribonucleic acid by highperformance liquid chromatography. Int J Syst Bacteriol 39, 159-167.

Moore, D. D. \& Dowhan, D. (1995). Preparation and analysis of DNA. In Current Protocols in Molecular Biology, pp. 2-11. Edited by F. M. Ausubel, R. Brent, R. E. Kingston, D. D. Moore, J. G. Seidman, J. A. Smith \& K. Struhl. New York: Wiley.

Saitou, N. \& Nei, M. (1987). The neighbor-joining method: a new method for reconstructing phylogenetic trees. Mol Biol Evol 4, 406-425.

Schleifer, K. H. \& Kandler, O. (1972). Peptidoglycan types of bacterial cell walls and their taxonomic implications. Bacteriol Rev 36, 407-477.

Steven, B., Chen, M. Q., Greer, C. W., Whyte, L. G. \& Niederberger, T. D. (2008). Tumebacillus permanentifrigoris gen. nov., sp. nov., an aerobic, spore-forming bacterium isolated from Canadian high Arctic permafrost. Int J Syst Evol Microbiol 58, 1497-1501.

Swindell, S. R. \& Plasterer, T. N. (1997). SEQMAN. Contig assembly. Methods Mol Biol 70, 75-89.

Ten, L. N., Im, W.-T., Kim, M.-K., Kang, M.-S. \& Lee, S.-T. (2004). Development of a plate technique for screening of polysaccharidedegrading microorganisms by using a mixture of insoluble chromogenic substrates. J Microbiol Methods 56, 375-382.

Ten, L. N., Jung, H.-M., Im, W. T., Yoo, S. A. \& Lee, S.-T. (2008). Lysobacter daecheongensis sp. nov., isolated from sediment of stream near the Daechung dam in South Korea. J Microbiol 46, 519-524.

Thompson, J. D., Gibson, T. J., Plewniak, F., Jeanmougin, F. \& Higgins, D. G. (1997). The CLUSTAL_X windows interface: flexible 
strategies for multiple sequence alignment aided by quality analysis tools. Nucleic Acids Res 25, 4876-4882.

Tschech, A. \& Pfennig, N. (1984). Growth yield increase linked to caffeate reduction in Acetobacterium woodii. Arch Microbiol 137, 163-167.

Widdel, F. \& Bak, F. (1992). Gram-negative mesophilic sulfatereducing bacteria. In The Prokaryotes, 2nd edn, pp. 3352-3378. Edited by
A. Balows, H. G. Trüper, M. Dworkin, W. Harder \& K. H. Schleifer. New York: Springer.

Widdel, F., Kohring, G. \& Mayer, F. (1983). Studies on dissimilatory sulfate-reducing bacteria that decompose fatty acids. III. Characterization of the filamentous gliding Desulfonema limicola gen. nov., sp. nov. and Desulfonema magnum sp. nov. Arch Microbiol 134, 286-294. 